\title{
Locative Memory and the Circulation of Mnemic Energy in The Winter's Tale
}

William E. Engel

\section{(2) OpenEdition}

Journals

Édition électronique

URL : http://journals.openedition.org/shakespeare/1957

DOI : 10.4000/shakespeare.1957

ISSN : 2271-6424

Éditeur

Société Française Shakespeare

Édition imprimée

Date de publication : 1 avril 2013

Pagination : 183-196

ISBN : 2-9521475-9-0

\section{Référence électronique}

William E. Engel, «Locative Memory and the Circulation of Mnemic Energy in The Winter's Tale », Actes des congrès de la Société française Shakespeare [En ligne], 30 | 2013, mis en ligne le 03 avril 2013, consulté le 22 avril 2019. URL : http://journals.openedition.org/shakespeare/1957 ; DOI : 10.4000/ shakespeare. 1957 


\section{Shakespeare et la mémoire}

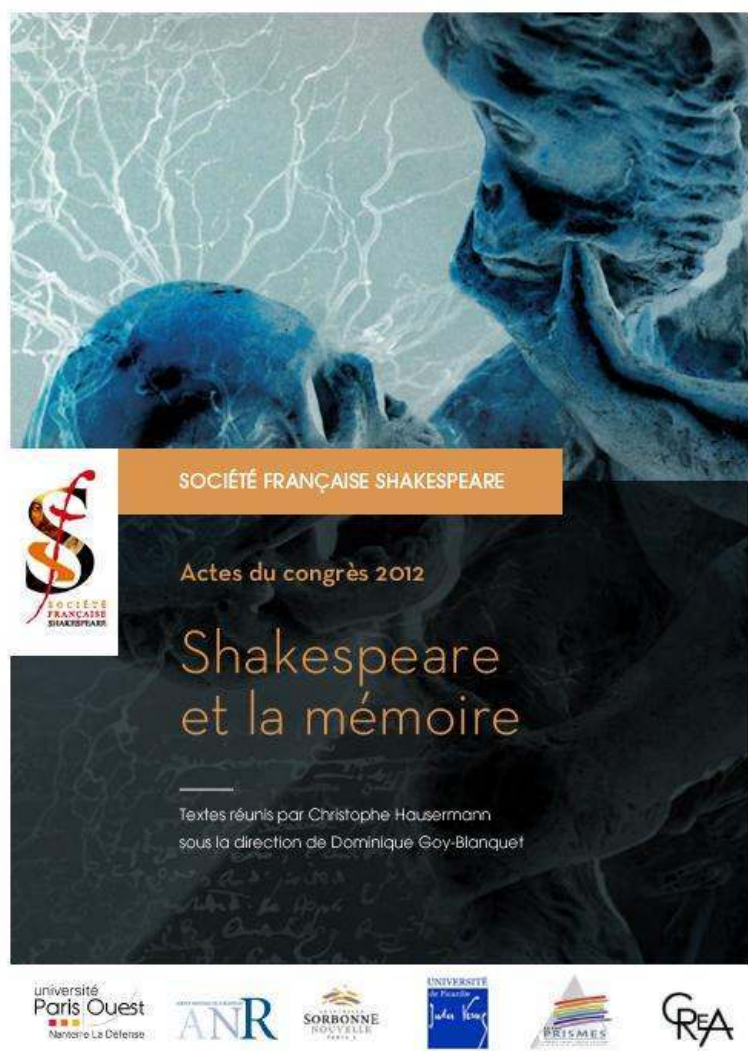

actes du Congrès

organisé par la

SOCIÉTÉ FRANÇAISE SHAKESPEARE

les 22, 23 et 24 mars 2012

textes réunis par

Christophe HAUSERMANN

sous la direction de

Dominique GoY-BLANQUET 


\section{COUVERTURE}

d'après l'affiche de Claire Colombet

conception graphique et logo

Pierre Kapitaniak

mise en page et corrections

Christophe Hausermann

(C) 2012 Société Française Shakespeare

Institut du Monde Anglophone

Université de Paris III - Sorbonne Nouvelle

5 rue de l'École de Médecine 75006 Paris

www.societefrancaiseshakespeare.org

Tous droits de traduction, de reproduction et d'adaptation réservés pour tous les pays 


\title{
LOCATIVE MEMORY AND THE CiRCULATION OF MNEMIC ENERGY IN THE WINTER'S TALE'
}

\author{
William E. Engel
}

The celebrated "statue scene" of Shakespeare's Winter's Tale (v.iii) has been subjected to many different critical approaches, and yet none so far has analyzed it in any sustained and critical way with respect to early modern mnemotechnic principles. This study therefore takes as its point of departure Renaissance rhetorical treatises on the Art of Memory so as to recover the basic aesthetic assumptions involved in the staging of this scene which in turn will provide a key for interpreting, in its original context, the emotional power evoked by this religiously resonant coup de théâtre. Such an approach has the added advantage of being able to indicate the extent to which Shakespeare self-consciously tapped into the immemorial reservoir of mnemic energy to achieve the intense dramatic effect that this scene both draws on and activates.

La célèbre « scène de la statue » du Conte d'hiver (v.iii) a donné lieu à de multiples analyses critiques, mais aucune approche jusqu'ici n'a examiné, de façon soutenue, l'influence des principes mnémotechniques employés au début de l'ère moderne. De ce fait, cette étude s'appuie sur les traités de rhétorique de la Renaissance portant sur l'« Art de la mémoire » afin de retrouver les prémisses esthétiques en jeu dans la réalisation de cette scène, ce qui rendra possible l'interprétation, dans son contexte d'origine, de la puissance émotionnelle évoquée par ce coup de théâtre à résonance religieuse. Une telle approche permet de comprendre dans quelle mesure Shakespeare aurait consciemment puisé dans le réservoir immémorial d'énergie mnésique pour atteindre le puissant effet dramatique généré par cette scène.

$\mathrm{T}$

he statue scene of The Winter's Tale (v.iii) justifiably is among the most celebrated and striking episodes in Shakespeare's oeuvre. ${ }^{2}$ While many different critical approaches have been used over the years, none to date has foregrounded the mnemotechnical model to which Shakespeare clearly was indebted. Analyzing the statue scene in terms of the early modern Memory Arts will provide an interpretive key both to the spiritual exercise of redemption with which the play is concerned, and also to the aesthetics of reclamation and recuperation which, after all, is the fundamental purpose of the ars memorativa -by means of places (loci) and lively images (imagines agentes). ${ }^{3}$

Accordingly, this essay takes as its point of departure Renaissance treatises on the Art of Memory so as to highlight the basic

\footnotetext{
${ }^{1}$ I am indebted to George Core, George Poe, and Nathan Stogdill for assistance in preparing this manuscript for publication. A preliminary version of this argument, focusing principally and at length on the place of the emblem in early modern mnemotechnics, is scheduled to appear in Rory Vincent Loughnane and Andrew Power, eds., Late Shakespeare: Texts and Contexts, Cambridge, C.U.P, 2012.

${ }^{2}$ All references to Shakespeare's plays follow The Complete Works, eds. Stanley Wells and Gary Taylor, $2^{\text {nd }}$ edition, Oxford, Clarendon Press, 2005.

3 See Frances Yates, The Art of Memory, 1966, rpt., Penguin Books, 1978, p. 18-28.
} 
aesthetic principles involved in its creation and staging, and then to demonstrate the extent to which Shakespeare tapped into the immemorial reservoir of myth and ritual which called forth and set in play the flow of mnemic energy. It is this activation of mnemic energy that in large measure will be shown to be responsible for the dramaturgical effectiveness of this scene and, indeed, account for the emotional power of the highly stylized resolution of the play's main concern with loss and recuperation, with death and regeneration.

Because of the importance of mnemic energy in the argument to follow, it is fitting to begin with a clarification of this and other key terms that will be brought to bear on The Winter's Tale. Mnemic energy has two main fields of meaning: the mythopoetic and the psychological, and this essay will build on both senses. First, as pertains to the mythopoetic, Mneme was one of the original muses from Boeotian folklore and myth. Later, in ancient Greece, there would be nine muses, with Mnemosyne, or Memory, being the mother of all arts. ${ }^{4}$ It is noteworthy that accompanying Mneme were her sisters Aoide (Song) and Melete (Contemplation). 5 Mediating between these two sisters, who were understood allegorically as the twin poles in the human psyche requisite for the creation of art, Mneme's special function is as a go-between. To her fall the tasks of collecting and maintaining order between and among the disparate snatches of song and the fleeting fragments of thought resulting from deep contemplation. Her role then is that of governor, keeping track of what has been called up and released so that it might be properly arranged and stored; she recovers what otherwise would be lost to oblivion and quite literally puts it in its place. It is a small step from here to see how it was that the notion of place became paramount in the imaginative spatialized constructs associated with the Memory Arts; and, more specifically, as will be discussed in what follows, locative memory. ${ }^{6}$

\footnotetext{
4 On Mneme as the mother of the Muses, see Ovid, Metamorphoses, trans. Frank Justice Miller, $3^{\text {rd }}$ edition, Cambridge, MA, Harvard University Press; London, William Heinemann Ltd. 1984, V. 268.

5 On the cult of the three original muses in Boeotia, see Pausanias, Description of Greece, translated by W.H.S. Jones and H.A. Omerod, Cambridge, MA, Harvard University Press; London, William Heinemann Ltd. 1918, IX.xxix.2; in this section "Melete" is rendered into English as "Practice."

6 The locus classicus of place-system mnemonics, also known as "artificial memory" schemes, is a rhetorical treatise attributed to Cicero, Rhetorica ad Herennium, III.xvi-xx; trans. Harry Caplan, Cambridge, Mass., Harvard University Press, 1954, p. 205-15.
} 
Equally germane to my analysis is the way that mnemic energy is treated in the human sciences, both cognitive psychology and evolutionary biology. Mnemic energy in these areas of inquiry denotes the retentive basis or basic principle in a mind or organism accounting for memory. As a broad theoretical construct, the term mneme "describes an organism's capacity to conserve the effects of stimulation and to interact with the environment on the basis of conserved experience." 7 More specifically, a mneme is a fundamental unit of stored memory. Richard Semon (1859-1918) developed this notion in his pioneering study Die Mneme (1904), which "examined not only the phenomenon of human memory but also advanced and attempted to support the thesis that the mechanisms of memory are hereditary and identical." 8 For Semon the mneme concerned more than mere recollection of facts or events; it was part of a larger theory that embraced the preservation of the effects of experience from one generation to the next. Hence the mneme is a "fundamental organic plasticity" that "in the organic world links the past and present in a living bond." 9

Although many of Semon's theories were slow to gain widespread acceptance in the scientific circles of his day, his lasting contribution to memory literature resides in his development of the idea of the engram, a term still in general use and about which more will be disclosed in the concluding section of this essay. For now it is sufficient to observe in passing only that the term engram refers to the change in the nervous system, namely "the memory trace" that preserves the effects of experience. This will be an instructive way to think about Hermione playing the role of -and being mistaken for -a statue. Further it will help us understand finally how her silence and stillness enable her to function paradoxically as both a repository for and a generator of-engrammic energy that subsequently is discharged by virtue of Paulina's careful management of setting, mood, and place.

\footnotetext{
7 Daniel L. Schacter, Forgotten Ideas, Neglected Pioneers: Richard Semon and the Story of Memory, Philadelphia, Taylor \& Francis, 2001, p. 121.

${ }^{8}$ Ibid., p. 248-9. Richard Wolfgang Semon, Die Mneme (1904) was first translated into English as The Mneme, London, George Allen \& Unwin, 1921, and Die mnemischen Empfindungen (1909) as Mnemic Psychology, London, George Allen \& Unwin, 1923.

${ }^{9}$ Semon, The Mneme, p. 12.
} 
It is in this regard that Paulina shows herself to be fully cognizant of the efficacy and operations of locative memory. Grounded in place-system mnemonics and derived from classical rhetoric, locative memory involves loci (places) and imagines agentes (lively images) arranged so that key bits of information can be deposited and recovered for future use. ${ }^{10}$ As in grammar and in linguistics, the locative in the Art of Memory denotes "place where," signaled in English with prepositions such as "in," "on," and "by." Shakespeare's recourse to the myths and stories that were part and parcel of the traditional Art of Memory served as the underlayer of his allusions to and evocations of mnemonic loci through staged spectacles which, in effect, revived and released powerful mnemic energy. Thus Paulina's seemingly miraculous effects are wrought as a result of the ceremony she stages in what are referred to specifically as her "gallery" and "chapel" (v.iii.10, 86). Her "removed house" (v.ii.106) with its focal statue conforms in all points to a typical Renaissance Memory Theatre. For example in a contemporary summation of the received wisdom of classical mnemonics for his early modern English readers, William Fulwood advises that one "take or choose a great and emptie house, to the whiche you must not go often but seldom." 11 This applies as well to the statue itself, which Paulina keeps "[l]onely, apart" (v.iii.18). Paulina's gallery and chapel involve a steady program of intense reflection conducing to reformation, redemption, and restoration. The vestigial mnemic energies conjured up through and compacted into the "statue" radiate out to affect Leontes and, by extension, the audience.

This same sense of compression holds for all manner of standard locative images whether those in artificial memory schemes or works of art in the world; secure in their niches, they can condense whole stories, allegories, or histories. Though they are of two kinds those found in paintings or rendered in stone - both have a long history of appearing to imitate the other. For example the backs of many paintings contain "grisaille" figures (monochrome or nearmonochrome visual simulations of statues) that are full of allegorical significance especially when seen with respect to the images on the

10 On "backgrounds and images" in "the artificial memory" and the importance of carefully placing memory cues for easy retrieval, see Rhetorica ad Herennium, III.xvi, 29-30, p. 208211.

${ }^{11}$ Guglielmo Grataroli, De Memoria (Zurich, 1553), trans. William Fulwood, The Castel of Memorie, London, 1562, sig. G8v. 
front of the main painting. Two notable examples are the exterior of Hubert and Jan van Eyck's Ghent Alterpiece (c.1432), where trompe l'œeil niches contain the figures of John the Baptist and John the Evangelist depicted as stone statues standing between full-colour images of the patrons facing toward them in prayer; and the reverse side of van der Weyden's "Portrait of Laurent Froimont" (c.1460), ${ }^{12}$ where the "name of the subject of the portrait was deduced from the grisaille: St. Lawrence (Laurent), with the instrument of his martyrdom, the gridiron." 13 The use of such compartmentalized niches in Netherlandish paintings is stunningly reminiscent of the associative practices at the heart of the Art of Memory. By the same token, the frontispieces of many important volumes of the day represented historical and allegorical figures within arches that were situated in an elaborate architectural framework. Exemplary in this regard is the 1611 King James Bible which shows Moses and Aaron within the two main niches flanking the central space where the title appears as if inscribed on a plain slab, a program which, because of its emphasis on a hierarchal priestly class in the principal figures depicted, has been interpreted as "an explicit rejection of Presbyterianism." 14

Moving on from these evocative if immobile depictions of statues (which are after all representations of people caught in a telling moment of expressive gesturing), we come to the allegorically outfitted "human statues" stationed along the route of a civic pageant or royal entry. ${ }^{15}$ Statues and tableaux vivants that came to life and spoke verse were a common feature of Renaissance progresses and triumphs. ${ }^{16}$ Statues strategically placed within artificial memory schemes were a

12 On the dating and provenance of this work, see John Oliver Hand and Martha Wolff, Early Netherlandish Painting, Washington, D.C., National Gallery of Art, 1987, p. 244.

13 Stephen Kemperdick, Rogier van der Weyden, trans. Anthea Bell, Cologne: Könemann, 1999, p. 9, 107.

14 See R. W. Lightbown, The Comely Frontispiece: The Emblematic Title-page in England, 1550-1660, London, Routledge and Kegan Paul, 1979, p. 107, 111.

15 David Evett, Literature and the Visual Arts in Tudor England, Athens and London, University of Georgia Press, 1990, p. 104. See also in this regard, with reference to specific programs, Sydney Anglo, Spectacle, Pageantry and Early Tudor Policy, Oxford, Clarendon Press, 1969; and David M. Bergeron, English Civic Pageantry, 1558-1642, London, Edward Arnold, 1971.

16 David M. Bergeron, Practicing Renaissance Scholarship: Plays and Pageants, Patrons and Politics, Pittsburgh, Duquesne University Press, 2000; David M. Bergeron, "Representation in Renaissance English Civic Pageants," Theatre Journal 40:3 (1988), p. 319-31; and, Stephen Orgel, The Illusion of Power: Political Theater in the English Renaissance, Berkeley and Los Angeles, University of California Press, 1975, esp. p. 40-42. 
main topic of discussion in classical rhetorical manuals, and later were used as mnemonic placeholders in the extended narratives of popular romances such as Sir Philip Sidney's Arcadia. ${ }^{17}$ And in private galleries such as Paulina's refuge, more in keeping with the traditional design of a Memory Theatre as discussed by Quintilian, painted statues conventionally were to be found on pedestals in clearly marked off and recessed spaces. ${ }^{18}$

In The Winter's Tale the central locus, or place, is the stage within the stage which is set off further by a curtain; and the animated image is the living art, namely the pseudo-statue. ${ }^{19}$ The presentation of such silent spectacles that involved a curtain, or "traverse," dates back at least to medieval times, when the cloth partition concealed and then dramatically was opened to reveal, or "discover," a religious tableau. ${ }^{20}$ Hallowed by a long tradition in England, the response elicited by such a tableau in The Winter's Tale thereby is assured to be one of amazement, reverence, and wonder. ${ }^{21}$

And yet it is not only Hermione who, as a memory image, constitutes the on-stage spectacle that draws on and partakes of recognizable features of the Memory Arts. While she is the central attraction to behold in Paulina's Gallery of Memory, Leontes plays the role of the fledgling mnemonist retrieving piecemeal what already has been set out to be discovered. It was not unusual for readers of mnemotechnic manuals of the day to appropriate for their own uses the components of an artificial memory system which had been set up by an author skilled in devising easy-to-use loci. John Willis, for example, includes an illustration of a stage divided by a column and

${ }^{17}$ William E. Engel, Chiastic Designs in English Literature from Sidney to Shakespeare, Farnham, Ashgate, 2009, p. 62-66.

18 Quintilian, Institutio Oratoria, trans. H. E. Butler, 1922, rpt., Cambridge, MA, Harvard University Press, 1979, XI.ii.20; for further development of this theme, see Lina Bolzoni, The Gallery of Memory: Literary and Iconographic Models in the Age of the Printing Press, University of Toronto Press, 2001, p. 227-235.

${ }^{19} \mathrm{My}$ analysis is not concerned with the so-called Pygmalion-effect which, as a recurring motif in the Western imagination, has been discussed ably and at length by Kenneth Gross, The Dream of the Moving Statue, Ithaca and New York, Cornell University Press, 1992, and Elizabeth Mansfield, Too Beautiful to Picture: Zeuxis, Myth, and Mimesis, Minneapolis, University of Minnesota Press, 2007.

${ }^{20}$ George R. Kernodle, From Art to Theatre: Form and Convention in the Renaissance, 1943, rpt. Chicago, University of Chicago Press, 1947, p. 10-12, 214-215.

${ }^{21}$ See Marion O'Connor, “'Imagine Me, Gentle Spectators': Iconomachy and The Winter's Tale," in Richard Dutton and Jean E. Howard, eds., A Companion to Shakespeare's Works, vol. IV, Oxford, Blackwell, 2003, p. 365-388. 
offers a range of sample mnemonic markers to put there. ${ }^{22}$ Leontes, in like manner, reclaims the values Paulina has invested in the main memory image. The audience thus catches an extraordinary glimpse into the ordinary workings of locative memory. For in the statue scene, we follow the commonplace procedure of mental ambulation as outlined by Quintilian: "places are visited in turn and the various deposits are demanded from their custodians, as the sight of each recalls the respective details." ${ }^{23}$ Hugh Plat similarly related these same basic principles to his late-Elizabethan audience: "you must make choice of some large edifice or building, whose Chambers or Galleries bee of some reasonable receipt, and so familiar vnto you, as that euerie part of each of them may present it selfe readily vnto your minde when you call for them." 24 And it is Paulina who will call for Hermione to "be stone no more" (v.iii.99).

The cunning artifice of the statue is reported to be "so near to Hermione [...] that they say one would speak to her and stand in hope of answer" (v.ii.99-101). Verisimilitude was a key component in the effective use of Memory Theatres. Willis paid meticulous attention to the details of setting up a mnemotechnic design within the mind's eye. His specifications could have served well for setting up such a stage like the one used for the statue scene: "Let there be imagined a Stage of smooth gray Marble, even and variegated with a party coloured border ... and raised a yard above the Level of the ground ... Let all the walls, that is, the opposite wall, \& two ends be wainscotted with Cypresse boards, so artificially painted and glewed, that the joints be indiscernible." 25

The aim of imagining such a true-to-life construction was to accommodate the display of lively and therefore more indelible memory images which would repose there -in this case, a statue so natural that Leontes exclaims: "Would you not deem it breathed, and that those veins / Did verily bear blood?" (v.iii.63-4). Art, or rather the idea of art, endows Hermione with a vitality and liveliness that she did not have before. "When Leontes sees the statue of Hermione," Joan Hartwig has argued, "he sees her as she is (even to her wrinkles) not as

\footnotetext{
22 John Willis, Mnemonica: or The Art of Memory, trans. Leonard Sowersby, London, 1661), p. 6.

23 Quintilian, Institutio Oratoria, XI.ii.20.

${ }^{24}$ Hugh Plat, The Jewell House of Art and Nature, London, 1594, sig. N, p. 81.

25 Willis, Art of Memory, p. 53.
} 
he had previously created her in his mad dream of evil. The statue renews Leontes' vision; and his perception of the statue, the true Hermione, allows her to return to life." 26

The more singular and distinctive the memory image, the more efficacious; thus Fulwood stresses, "in placing or setting of the images or figures in their places the thing is alwaies to be placed with a mery, a merueilous or cruel act [for such] things do ... moue ye senses, \& better styre up the Memorie." 27 This is certainly the case of the uncanny "dead likeness" of Hermione (v.iii.15), made all the more striking as a memory image when we recall the history of her cruel treatment, her marvellous rescue from oblivion, and the merry reunion with her grateful daughter and contrite husband.

The statue then, as a combination of tableau vivant and mnemic repository of recessed meaning activated in the dynamics of its reception, feeds Leontes' astonishment and brings his virtuous wife to mind and, in the end, to life. The representation of art here, creating something more real and wonderful than Leontes otherwise might have imagined possible, is highlighted further by its having been filtered through and construed in terms of mnemotechnics. Further, owing to her Griselda-like patience, uncommon endurance, and silent suffering, Hermione resembles more a portrait of a saint than an emblem of slandered virtue. And this difference may well provide a key for recovering an as yet unnoticed source of Shakespeare's evocation of this kind of mnemically charged image.

In what may have been a subtle gesture of misdirection on Shakespeare's part, one of the three gentlemen alludes to Giulio Romano as the artist responsible for Paulina's marmoreal likeness of Hermione painted to the life (v.ii.96). And yet this Italian Renaissance master, who studied with and often finished paintings by Raphael (such as "St. Catherine defeats the Dragon", currently at the Louvre), was not known as a sculptor. With this in mind, a more likely possibility for the polychrome aesthetic effect Shakespeare aimed to conjure in his audience is the hyperrealism of Spanish painted sculptures of saints embellished with glass eyes, resin tears, and ivory teeth. Indeed, Polixenes and Leontes respond accordingly to the work

\footnotetext{
26 Joan Hartwig, Shakespeare's Tragicomic Vision, Baton Rouge, LA, Louisiana State University Press, 1972, p. 25.

${ }^{27}$ Fulwood, Castle of Memorie, sig. H6.
} 
of living art, one after the other: "The very life seems warm upon her lip. / The fixure of her eye has motion in't" (v.iii.66-7). So the original audience of the first performances of The Winter's Tale would have seen at a glance the kind of participatory quasi-religious response that was being set in place and elicited by this painted statue that clearly was part of cutting-edge baroque artifice. ${ }^{28}$ Extremely popular in Spanish lands during the early XVII ${ }^{\text {th }}$ century, the exaggerated realism and harsh sense of pathos of such statues brought the viewer into a special communion with the suffering of the depicted saint, martyr, or saviour. It is in this light that we can see Hermione as a martyr, sacrificial victim, and redeemer. Recalling both the stages of the trionfi and the reward of faithful martyrs, her steadfastness and purity exacts a victory over Death and channels this mnemically to the audience.

Despite anti-Spanish sentiment in Elizabeth's reign, it is hardly surprising that a Spanish art-form was favourably viewed in the Stuart court. James had an "instinct for peace"; ${ }^{29}$ he established and maintained diplomatic relations with Spain and the Spanish Netherlands leading up to and following the peace treaty of 1604 negotiated primarily by Robert Cecil and Henry Howard. Cecil was well-known as a patron of the arts, ${ }^{30}$ and no doubt would have been attentive to what was there to be seen during the decade when proposals and counter-proposals were being discussed. ${ }^{31}$ Many Jacobean diplomats and courtiers were in Spain and also, directly across the English Channel, in the Spanish Netherlands. And so during the time when Shakespeare was writing The Winter's Tale, plenty of Englishmen and Scots had extensive knowledge of Spanish cultural life and customs, including the vogue for polychrome statues.

\footnotetext{
28 On the staging of plays by the King's Men at Blackfriars and the performative exigencies of this semi-private space, see Gordon McMullan, "What is a 'late play'?", in Catherine M.S. Alexander, ed., The Cambridge Companion to Shakespeare's Last Plays, Cambridge, C.U.P, 2009, p. 8.

${ }^{29}$ Karen Britland, "Politics, religion, geography and travel: historical contexts of the last plays," in The Cambridge Companion to Shakespeare's Last Plays, op. cit., p. 79.

$3^{0}$ Stefani Brusberg-Kiermeier, " 'Never Shall my sad eies againe behold those pleasures': Aemilia Lanyer and Her Idealization of Tudor Court Life," in Thomas Betteridge and Anna Riehl, eds., Tudor Court Culture, Selinsgrove, PA: Susquehanna University Press, 2010, p. 137.

${ }^{31}$ W. Brown Patterson, King James VI and I and the Reunion of Christendom, C.U.P, 1997, p. 70-74.
} 
In a recent exhibition of just such works at the National Gallery in London, ${ }^{32}$ one reviewer reported that "clergy and groups of interested lay people could be seen in the gallery every day and the silent awe with which gallery goers absorbed the show was palpable."33 That these statues, even when viewed in a secular setting, are still capable of inspiring silent awe accords well with Paulina's description of Leontes' response when confronted with the lively "dead likeness" of Hermione: "I like your silence; it the more shows off / Your wonder" (v.iii.21-22). This is consonant with Paulina's view expressed earlier in her attempt to reconcile Leontes with Hermione by showing him the infant Perdita: "The silence often of pure innocence / Persuades when speaking fails" (II.ii.44-5). This understanding of silence provides further insight into the mythopoetic associations that tacitly trigger the recollection of yet another set of values beyond and in addition to the implications already noted. As Charles Moseley put it, "Hermione thus ceases to be simply a character, but becomes part of a symbolic economy transcendent of the characters, recollected and understood in our memory of the play." 34

Indeed one association in particular that is part of this symbolic economy must be mentioned explicitly because, by virtue of similarity in sound and sense, it so seamlessly seeps into the spectators' mnemic unconscious: the Greek god Hermes. There is an unmistakable trace of Hermes the psychopompos, the conductor of the dead, in Hermione. Hermes was "the intermediary between the upper and lower worlds." 35 Stone pillars, called hermae, were placed on graves, and Hermes was honored in the prayers for the dead. For like Hermes, Hermione inhabits a liminal realm between the living and the dead. In much the same way that Hermione, masquerading as an effigy of stone in the world of the play, is absorbed into the world of silent stone, so too

32 "The Sacred Made Real: Spanish Painting and Sculpture 1600-170o," The National Gallery, London (12 October 2009 - 24 January 2010), and the National Gallery of Art, Washington, DC (28 February - 31 May 2010).

33 Nicholas Cranfield, review of "The Sacred Made Real," The Daily Episcopalian: www.episcopalcafe.com/daily/art/review_the_sacred_made_real.php.

34 Charles Moseley, "The literary and dramatic contexts of the last plays," in Rory Vincent Loughnane and Andrew Power, eds., Late Shakespeare: Texts and Contexts, Cambridge, C.U.P, 2012, p. 57.

35 Oscar Seyffert and Henry Nettleship, A Dictionary of Classical Antiquities, Mythology, Religion, Literature and Art, New York, Macmillan, 1891, p. 287. 
stone is associated with the presence of Hermes in the world. ${ }^{36} \mathrm{He}$ is one of the few Greek gods whose name etymologically is transparent, and it means "he of the stone-heap." 37 Consistent with his genial nature and skill at helping wayfarers, Hermes became the god of the crossroads where heaps of stones were erected in his honor by each passer-by who added a stone. Ithyphallic pillars, or "herms" as they are called in English, stood at the edge of farms both as a boundary marker as well as a totem protecting one's property. Hermione too marks such a boundary where Leontes is concerned, and so the restoration of harmony (which like Hermes also is a cognate of the name Hermione) taps into immemorial mnemic associations of property and propriety. The restoration of harmony in the play is the result of mnemonically oriented conjuring by means of which Hermione is restored to her proper and former place in all respects: cosmic, social, and domestic. Implicitly evoking and embodying the powers associated with Hermes, she moves from apparent death to life, from being a non-person to becoming once again the center of court culture, from strumpet to sainted wife.

Along with Leontes we are invited to, and cannot help but, retrieve these symbolic and social meanings reposited in Hermione. It is a double process, activating within us some long-untouched nostalgia for recovering what is believed to be lost, and expressed through mnemic energy released by means of the staged spectacle. The range of released composite associations need then to be re-lodged somewhere else, namely within the chambers of one's mind. Paulina dutifully directs and constrains how the audience, principally Leontes, takes in -and is taken in by - what is seen and experienced. This leads to the other sense of re-covering at work in this scene; namely, of covering over, so as not to keep foremost in memory, what inhibits experiencing the wonder and delight at the recovery of Hermione specifically, the knowledge of what she and Perdita endured as a result of Leontes' extreme cruelty, as well as the deaths of young Mamillius and the aged Antigonus.

This selective forgetting, integral to the work of restorative and healing memory, becomes a part of our experience too whether or not

\footnotetext{
$3^{6}$ C. Kerényi, The Gods of the Greeks, 1951, rpt. London, Thames and Hudson, 2008, p. 170.

37 Martin P. Nilsson, History of Greek Religion, Oxford, Clarendon, 1949, p. 109.
} 
we are aware of the resonant activation, generation, and transfer of engrammic energy. ${ }^{38}$ Semon's theory of engrammic energy stressed the importance of retrieving a fraction of the stored memory to regain access to the engram. In his critical examination of how this theory applied to Aby Warburg's lifework on the nature of symbolic forms and cultural memory, Ernst Gombrich observed: "The potential energy conserved in this 'engram' may, under suitable conditions, be reactivated and discharged - we then say the organism acts in a specific way because it remembers the previous event. This goes for the individual no less than for the species. It was this concept of mnemic energy, preserved in 'engrams', but obeying laws comparable to those of physics which attracted Warburg."39

Following Semon's theory quite closely, Warburg maintained that embedded within certain conventional forms of highly stylised symbolic artifice, consistent with Paulina's animated statue, we can detect the seed of some enduring aspect of shared memory, the visible remnant of engrammic transference. It is preserved and transmitted by way of an energy not fully known to the physical world - until recently. Current research in neuroscience with Alzheimer patients, using the stimulus of emotionally powerful scenes from movies, led to the conclusion that cell assemblies, specific to hippocampal neurons, code for the temporal relationships between sensory events. $4^{0}$ This coding seems to have been brought on by the patients' profound if inarticulable response to these select scenes which they reported made them feel good even though most could not recall what precisely they had seen.

In line with this, throughout the play Paulina finds the most apt ways to stimulate strong emotional responses to colour past events. Specifically she reminds people, especially Leontes, of what too easily is allowed to slip from memory. As regards the courtiers pressing Leontes to remarry, Paulina rebukes them that "[t]here is none worthy, / Respecting her that's gone" and reminds them of Apollo's oracle (v.i.34-40); she has Leontes swear "[n]ever to marry but by my free leave" (v.i.70). She also reminds Leontes how he "killed" Hermione

\footnotetext{
38 An engram is the trace left by any event affecting living matter.

39 E. H. Gombrich, Aby Warburg: An Intellectual Biography, University of Chicago Press, 1986, p. 242.

40 Rory Paz (et. al.), "A neural substrate in the human hippocampus for linking successive events," Proceedings of the National Academy of Sciences 107:13 (2010), p. 6046-51.
} 
(v.i.15). Her goal all along has been to reunite Leontes and Hermione, but only after certain conditions have been met. In her getting Leontes to retrieve, process, and act on the received information - in effect, to recover the engram - we catch a glimpse of the moral component, driven by emotional responses, of a reprogramming technology associated with locative memory and which owes its efficacy to an evocation and release of mnemic energies.

Shakespeare superimposes onto Hermione a series of mythopoetic associations and quasi-religious tendencies that profoundly affect the audience by virtue of, in part, the latent mnemic energies activated in the performance of the statue scene. There is thus an unlooked for and perhaps surprising residual theurgic resonance in Hermione as a memory image associated both with Hermes the psychopomp and also with saints and martyrs. When one takes to heart Paulina's directive to "awake your faith" (v.iii.95), one becomes susceptible to the act of recovering seeds of the primordial and fundamental truths of things at their source, especially when aided by the principles of the Memory Arts. Such a critical understanding of how traditional memory images can be deployed to signal and convey more than just "phenomena in consciousness" accords well with Semon's view of the engram as denoting a "permanent change wrought by a stimulus" which is set in play by virtue of the activation of "the totality of the mnemic potentialities." 41

And so the parting image in The Winter's Tale is of penitent and permanently changed - Leontes receiving grace thanks to Paulina's having brought together the totality of those mnemic potentialities which highlight Hermione's clemency, innocence, and salvific power. The concluding vignette, which recalls the earlier medieval tableaux vivants, Renaissance allegorical figures situated within mnemonic niches, and the hyper-realism of baroque polychrome statues, thus brings together and tacitly evokes the associations of martyr, saint, and saviour. Hermione need not - and indeed does not-speak to Leontes in the closing scene. As Shakespeare seems to have known intuitively (and because it makes for effective theatre), mnemic charges like those associated with locative memory take us to a place before and beyond words. The sixteen-year gap of time having been filled with proper penance thereby is

\footnotetext{
${ }^{41}$ Semon, The Mneme, p. 24.
} 
196 William E. ENGEL

overcome, faith restored, and life redeemed by means of art - but, most especially, by the Art of Memory.

William E. Engel

Sewanee, The University of the South 